\title{
KAJIAN KEMAMPUAN BERPIKIR KRITIS SISWA MELALUI PENDEKATAN AKTIVITAS AESOP'S DALAM PEMBELAJARAN KIMIA MATERI HIDROKARBON
}

\section{The Study of Students' Critical Thinking Skills Through the Approach of Aesop's Activities In Learning the Chemistry On Hydrocarbon Material}

\author{
Pebbriani Clarita Lewier*, Kelly Sinaga \\ Pendidikan Kimia, Universitas Pelita Harapan, Tangerang \\ *email: claritalewier15@gmail.com
}

\begin{abstract}
Abstrak. Berpikir kritis merupakan salah satu atribut yang harus dikembangkan dalam pembelajaran karena dengan berpikir kritis seseorang dapat menganalisis, menjelaskan dan menyimpulkan informasi yang diterima sehingga dapat memahami inti pembelajaran. Fakta yang terjadi siswa masih kurang dalam berpikir kritis yang dapat dilihat dari kurangnya kemampuan siswa menganalisis informasi yang diberikan karena cenderung menerima informasi tanpa mengolahnya terlebih dahulu. Maka penting bagi guru mengembangkan kemampuan berpikir kritis siswa saat pembelajaran materi hidrokarbon. Pendekatan aktivitas Aesop's dapat membantu meningkatkan kemampuan berpikir kritis melalui keterampilan berbasis observasi, logika hipotesis deduktif, analisis data dan inkuiri terbimbing. Sehingga tujuan dari artikel ini untuk mengkaji kemampuan berpikir kritis siswa dalam materi hidrokarbon melalui pendekatan aktivitas Aesop's. Metode penelitian terdiri atas dua tahap yaitu: 1) Studi literatur menggunakan 31 referensi untuk mengkaji kemampuan berpikir kritis dan pendekatan aktivitas Aesop's. 2) Penerapan dan observasi disalah satu sekolah Kristen di Jakarta. Hasil pembahasan yang diperoleh adalah: 1) Siswa dapat menjelaskan data faktual dengan jelas di LKS. 2) Memahami pertanyaan pada soal kuis dan menjawab dengan benar. 3) Menarik suatu kesimpulan pembelajaran berdasarkan hasil diskusi siswa. Hasil dari pendekatan aktivitas Aesop's tersebut dapat disimpulkan mampu menuntun siswa untuk mengembangkan kemampuan berpikir kritis dan dapat digunakan untuk menjelaskan informasi dengan pengetahuan yang benar sesuai dengan kehendak Tuhan maka saran dalam penulisan ini adalah diperlukan penelitian lebih lanjut agar dapat berlangsung dengan efektif.
\end{abstract}

Kata Kunci : berpikir kritis, hidrokarbon, pendekatan aktivitas Aesop's

\begin{abstract}
Critical thinking is one of the attributes that must be developed in learning because by thinking critically one can analyze, explain and conclude the information received so that he can understand the core of learning. The facts that occurred was that students were still lacking in critical thinking which could be seen from the lack of students' ability to analyze the information provided because they tended to receive information without processing it first. So, it was important for teachers to develop students' critical thinking skills in learning hydrocarbon material. Aesop's activity approach can help improve critical thinking skills through observation-based skills, deductive logic hypotheses, data analysis, and guided inquiry. Therefore, the purpose of this paper was to examine students'
\end{abstract}


critical thinking skills in hydrocarbon materials through Aesop's activity approach. The research method consisted of two stages, namely: 1) A literature study used 31 references to study critical thinking skills and Aesop's activity approach. 2) Application and observation in a Christian school in Jakarta. The results of the discussion obtained were: 1) Students could explain factual data clearly in the worksheet. 2) Students understood the questions on the quiz and answered them correctly. 3) Students drew a learning conclusion based on the results of student discussions. The results of the Aesop's activity approach concluded that it was able to guide students to develop critical thinking skills and could be used to explain information with the correct knowledge by following God's will, so the advice in this paper was that further research was needed to take place effectively.

Keywords: critical thinking, hydrocarbons, Aesop's activity approach

\section{PENDAHULUAN}

Salah satu peran yang memiliki pengaruh yang besar dalam pendidikan adalah guru. Tugas utama seorang guru dalam Undang-Undang Republik Indonesia No. 14 Tahun 2005 menyatakan bahwa guru merupakan seorang pendidik profesional, dengan tugas utama mendidik, mengajar, membimbing, mengarahkan, melatih, menilai, dan mengevaluasi siswa pada pendidikan anak usia dini jalur pendidikan formal, pendidikan dasar dan pendidikan menengah (Telaumbanua, 2018). Guru akan berhadapan langsung dengan siswa yang memiliki beragam karakter karena setiap orang diciptakan Tuhan dengan memiliki berbagai keunikan termasuk guru. Menurut pandangan Kristen guru maupun siswa adalah ciptaan Allah yang memiliki gambar dan serupa dengan Allah (Kej 1:26-27) artinya bahwa manusia sangat berharga bagi Tuhan. Manusia adalah pribadi yang dapat membuat suatu keputusan-keputusannya sendiri sehingga, manusia dapat dikatakan sebagai ciptaan Tuhan yang unik dan berharga.

Pengambilan keputusan yang baik dan dapat di pertanggung jawabkan harus didasari pada informasi atau pengetahuan yang benar yang dapat dijelaskan secara sistematis serta dapat diterima sehingga diperlukan suatu kemampuan berpikir kritis. Hal ini didukung oleh Rositawati (2019) yang menyatakan akan kemampuan seseorang dalam berpikir kritis diperlukan agar membantu pembelajar dalam mengelola suatu pikiran dan memperoleh cara belajar yang sesuai, mengetahui makna belajar dan mengetahui inti pembelajaran. Berpikir kritis terdiri dari pengembangan suatu pandangan, mengamati dan menduga, membandingkan dan membedakan, membuat dugaan/kesimpulan, memprediksi atau menafsirkan, menguji dan mengevaluasi dugaan, mengenal sebab dan akibat, membedakan fakta-fakta yang relevan dan yang tidak relevan, menarik kesimpulan, membangkitkan dan menilai solusi, mengenal kontradiksi dan meringkas (Surmani, 2015). Hal yang sama juga didukung dalam pandangan Kekristenan yang menyatakan bahwa keputusan yang baik memampukan seseorang mengikuti perintah untuk mengasihi Tuhan Allah dengan segenap akal budi (Mat. 22:37) hal tersebut berlandaskan Alkitab seperti dalam Roma 12:2 yang menyajikan standar akal budi yang diperbaharui untuk menguji sesuatu; sedangkan bagian ke dua menggambarkan pemikiran kritis, yakni ketelitian dalam menguji dan memilih yang baik dan berkenan kepada Allah dengan yang tidak (Pardede, 2016). 
Fenomena yang terjadi di Program Pengalaman Lapangan 2 (PPL 2) yang telah dilaksanakan selama satu bulan di salah satu sekolah Kristen di Jakarta adalah ditemukan beragam permasalahan pada siswa kelas XI selama pembelajaran kimia materi hidrokarbon. Salah satu permasalahan yang ditemukan adalah kurangnya kemampuan berpikir kritis dalam pembelajaran yang dapat dilihat ketika siswa kurang memahami konsep dari materi tata nama senyawa hidrokarbon karena siswa lebih cenderung menghafal langkah kerja dari contoh soal, hal ini dilihat saat guru memvariasikan pertanyaan dari soal yang diberikan kepada siswa dan siswa kesulitan untuk menjawabnya. Siswa juga kurang memiliki inisiatif yang mandiri dalam bertanya maupun menjawab pertanyaan dari permasalahan yang diberikan padahal salah satu pemikir kritis yang ideal menurut Facione dalam Rositawati (2019) adalah memiliki rasa ingin tahu.

Ditinjau dari permasalahan yang ada, maka guru sebagai pendidik yang profesional perlu untuk meningkatkan kemampuan berpikir kritis dalam pembelajaran kimia materi hidrokarbon agar siswa dapat memahami inti dalam pembelajaran, terlebih lagi guru Kristen yang memiliki tujuan untuk membawa siswanya kepada suatu hubungan yang menyelamatkan dengan Yesus Kristus (Knight, 2009) karena dengan memiliki kemampuan berpikir kritis maka siswa dapat menggunakan kemampuan berpikir yang telah diberikan Tuhan dengan maksimal agar dapat menganalisiss, menjelaskan dan mengambil suatu keputusan serta mengatasi permasalahan dalam hidup yang sesuai dengan kehendak Tuhan.

Putri, Suwatno, dan Sobandi (2018) menjelaskan bahwa berpikir kritis adalah situasi dalam menganalisis masalah melalui evaluasi potensi, pemecahan masalah, dan sintesis informasi dalam menentukan keputusan. Kemampuan berpikir kritis tersebut dapat dilihat dari indikator berpikir kritis yaitu: (1) Memberikan penjelasan sederhana; (2) Keterampilan mengenal dan memecahkan masalah; (3) Menarik kesimpulan. Oleh sebab itu, penulis menggunakan pendekatan aktivitas Aesop's karena pendekatan tersebut sesuai dengan karakteristik materi hidrokarbon dan indikator dari berpikir kritis tersebut. Menurut Sudarmin, Prasetya, dan Pahlevi (2012) pendekatan aktivitas Aesop's terbagi menjadi empat aktivitas yaitu: 1) Keterampilan berpikir berbasis observasi. 2) Logika hipotesis-deduktif. 3) Kemampuan analisis data. 4) Inkuiri terbimbing. Ia juga menjelaskan bahwa pendekatan pembelajaran mengkoordinasikan pada suatu aktivitas dan metode yang terarah pada tujuan (Goal-Directed). Pendekatan aktivitas Aesop's membuat pembelajaran lebih menyenangkan karena menciptakan suatu pengalaman yang bermanfaat dalam pembelajaran kimia materi hidrokarbon dan terarah pada tujuan pembelajaran sehingga apabila dirancang dengan baik maka siswa akan memiliki pengalaman yang kaya akan informasi pembelajaran kimia dengan menggunakan kemampuan berpikir kritis dengan maksimal (Alfathy, Susanto, dan \& Marwoto, 2018). Bertolak dari hal tersebut maka artikel ini akan membahas pendekatan aktivitas Aesop's dalam mengembangkan kemampuan berpikir kritis siswa dalam pembelajaran kimia materi hidrokarbon melalui aktivitas dengan metode ilmiah yaitu keterampilan berpikir berbasis observasi, logika hipotesis deduktif, kemampuan analisis data, dan inkuiri terbimbing serta yang terarah pada tujuan pendidikan Kristen. Dengan tujuan dari penulisan artike ini adalah mengkaji kemampuan berpikir kritis siswa kelas XI dalam pembelajaran kimia materi hidrokarbon melalui pendekatan aktivitas Aesop's. 


\section{METODE PENELITIAN}

Pembahasan ini dikaji dengan menggunakan dua tahap yaitu: 1) Studi literatur menggunakan 31 referensi untuk mengkaji kemampuan berpikir kritis dan pendekatan aktivitas Aesop's, 2) Penerapan dan observasi di salah satu sekolah Kristen di Jakarta. Metode pengumpulan data yang digunakan adalah studi pustaka dan observasi dengan jenis data sekunder dan primer. Sebelum mengkaji lebih dalam tentang data yang diperoleh, maka penting untuk terlebih dahulu memahami permasalahan yang ditemukan selama PPL 2 di salah satu sekolah Kristen di Jakarta.

\section{HASIL DAN PEMBAHASAN}

Berbagai permasalahan ditemukan saat pembelajaran salah satunya adalah kemampuan berpikir kritis pada siswa kelas XI. Berpikir kritis merupakan salah satu atribut yang harus dikembangkan dalam proses belajar mengajar karena proses pembelajaran yang efektif dibutuhkan kerja sama antara guru dan siswa yang memiliki kemampuan dalam berpikir kritis. Dengan demikian, inti pembelajaran dapat tersampaikan kepada siswa. Membahas hal tersebut maka penting untuk memahami terlebih dahulu natur manusia sebagai ciptaan Tuhan yang segambar dan serupa dengan Allah. Sebagaimana analogi gunung es yang dikemukakan oleh Sigmund Freud bahwa gunung es yang ada pada permukaan saja tidaklah cukup karena pemikiran dasar memiliki porsi yang lebih besar yaitu $80-90 \%$ (Taufiq, 2016). Artinya adalah pemahaman dasar akan pentingnya berpikir kritis harus dipahami terlebih dahulu karena dengan demikian maka akan lebih mudah seseorang berusaha untuk mengembangkan kemampuan berpikir kritis.

Manusia yang diciptakan segambar dengan Allah memiliki akal budi untuk mengelola dan menguasai bumi sehingga melalui pemikiran, manusia bisa mengerti kebenaran Allah yang disingkapkan (Berkhof, 2016). Berdasarkan hal tersebut maka perlu disadari bahwa setinggi-tingginya seseorang memiliki pengetahuan tidak akan melampaui pemikiran sang pencipta-Nya. Ketika manusia telah jatuh dalam dosa maka manusia berada pada posisi yang hanya memiliki satu pilihan yaitu berdosa, artinya manusia tidak bisa untuk tidak berdosa karena natur manusia telah tersentuh oleh dosa yang membuat suatu ketidakmampuan spiritual (Berkhof, 2017) sehingga segala sesuatu yang dipikirkan manusia berujung pada dosa. Berdasarkan hal tersebut, maka tidak heran bila ditemukan beberapa siswa yang kurang berusaha dalam menggunakan akal budinya secara maksimal yaitu berpikir kritis dalam menanggapi suatu permasalahan. Berikut ini adalah data yang menunjukkan refleksi pengajar akan beberapa siswa yang kurang meningkatkan kemampuan berpikir kritis selama pembelajaran materi hidrokarbon dapat dilihat pada tabel 1:

Tabel 1: Data refleksi pengajar

\begin{tabular}{lll}
\hline No & Tanggal refleksi & Kalimat dalam refleksi \\
& 30 Juli 2019 & $\begin{array}{l}\text { Tidak ada siswa yang berani untuk maju ke } \\
\text { depan }\end{array}$ \\
& $\begin{array}{l}\text { Beberapa siswa belum secara kritis mengerjakan } \\
\text { 01 Agustus 2019 }\end{array}$ \\
& $\begin{array}{l}\text { yang mengerjakan soal harus sesuai dengan } \\
\text { contoh yang diberikan }\end{array}$ \\
\hline
\end{tabular}


08 Agustus 2019

12 Agustus 2019

13 Agustus 2019
Siswa hanya duduk tenang mendengarkan dan menunggu informasi

Ada beberapa yang kurang teliti sehingga mendapat nilai di bawa rata-rata

Beberapa siswa ada yang masih memiliki pemahaman bahwa kimia adalah pembelajaran yang sulit di mengerti dan harus serius ketika belajar kimia

Data tersebut merupakan hasil refleksi dari pengajar yang melihat akan kendala di dalam kelas saat pembelajaran berlangsung yang menunjukkan karakteristik siswa yang kurang menggunakan kapasitas berpikir dengan maksimal, berdasarkan permasalahan tersebut, maka hal mendasar yang penting untuk dipahami adalah bahwa manusia telah ditebus oleh karena kasih karunia Tuhan yang menyelamatkan manusia sehingga, manusia dapat memiliki pilihan untuk tidak berbuat dosa atau berbuat dosa artinya siswa dapat memiliki pilihan untuk menggunakan kapasitas berpikir dengan maksimal.

Allah memperlengkapi manusia dengan akal budi agar dapat membedakan kehendak Tuhan dan yang bukan kehendak Tuhan sehingga terciptalah suatu keputusan yang benar di dalam Tuhan (Calvin, 2015). Yohanes 14:6 memaparkan dengan jelas bahwa hanya di dalam Yesus jalan kebenaran dan hidup sehingga pemikiran seseorang harus terarah dalam satu fokus tujuan yaitu Yesus Kristus. Augustinus dalam Bavinck, (2003) juga menyatakan bahwa selain rasio ia menempatkan otoritas dan iman sebagai satu-satunya yang memimpin kepada pengetahuan yang benar tentang Allah. Artinya bahwa dalam mempelajari sesuatu kita harus memiliki iman dalam Yesus Kristus karena dengan demikian maka manusia akan dimampukan dalam mengambil suatu keputusan yang benar dan melakukan segala sesuatu sesuai dengan kehendak Tuhan.

Pemaparan tersebut merupakan tantangan bagi guru dalam menyampaikan materi pembelajaran dengan dasar dan arah yang tepat sehingga mengurangi potensi disfungsi dan mendorong pengalaman pembelajaran siswa (Pazmiño, 2001). Terlebih lagi guru Kristen yang memiliki tujuan untuk membawa siswanya kepada `suatu hubungan yang menyelamatkan dengan Yesus Kristus.

Berbagai komponen diterapkan dalam pembelajaran baik itu suatu model pembelajaran, metode, strategi, pendekatan dan teknik. Segala usaha dilakukan untuk menciptakan suatu pembelajaran yang efektif dan terarah pada tujuan sehingga menuntun siswa untuk aktif dalam pembelajaran. Berbagai komponen pembelajaran dapat diterapkan asalkan tetap mencakup pada suatu usaha guru untuk menuntun siswa memperdalam pengertian tentang dunia ciptaan Tuhan dan tugas, tanggung jawabnya di dunia serta yang terpenting adalah menuntun siswa pada suatu relasi dengan Tuhan.

Berdasarkan pandangan tersebut maka dilakukan penerapan pendekatan aktivitas Aesop's dalam pembelajaran materi hidrokarbon yang dapat dilihat pada tabel berikut ini: 
Tabel 2: Penerapan pendekatan Aesop's dalam materi hidrokarbon

\begin{tabular}{ll}
\hline \multicolumn{1}{c}{ Aktivitas Aesop's } & Pengalaman Belajar \\
\hline Inkuiri terbimbing & Siswa dapat menentukan nama senyawa \\
& hidrokarbon (alkana, alkena, alkuna) \\
Keterampilan berpikir berbasis & Siswa dapat menyimpulkan pembelajaran melalui \\
observasi & sebuah lagu \\
Logika hipotesis deduktif & Siswa memprediksi soal-soal isomer dikaitkan \\
& dengan jenis isomer \\
Analisis data & Siswa menganalisis data tabel sifat fisik \\
& hidrokarbon yang terdapat pada buku paket. Siswa \\
& dapat menjelaskan sifat fisik hidrokarbon \\
\hline
\end{tabular}

Penerapan tersebut dilakukan secara bertahap selama enam kali pengajaran. Berbagai macam dinamika terjadi di dalam kelas sehingga guru dituntut untuk memegang kendali yang besar dalam mengelola pembelajaran agar tercapai tujuan pembelajaran selain itu, penerapan aktivitas Aesop's juga harus disesuaikan dengan karakteristik dari materi hidrokarbon yang terdiri dari pengetahuan procedural, konseptual, dan faktual.

Penerapan pendekatan aktivitas Aesop's pertama kali dilakukan di pengajaran pertama dan kedua yaitu inkuiri terbimbing karena materi yang dipelajari adalah aturan tata nama alkana, alkena, dan alkuna secara International Union of Pure and Applied Chemistry (IUPAC) yang memiliki karakteristik pengetahuan prosedural artinya diperlukan suatu pemahaman secara sistematis akan langkah-langkah yang telah ditentukan IUPAC. Selain itu, langkah-langkah dari tata nama senyawa hidrokarbon juga memerlukan suatu konsep pemahaman dari materi sebelumnya tentang sifat dari karbon dan hidrogen. Dengan demikian kemampuan berpikir kritis siswa dapat menjelaskan penamaan suatu senyawa hidrokarbon dengan mengkaitkan konsep pembelajaran sebelumnya. Aktivitas inkuiri terbimbing dapat membuat siswa memiliki rasa ingin tahu dan guru yang berperan sebagai fasilitator dapat membimbing siswa dalam pengerjaan soal. Hal tersebut sejalan dengan respons yang ditunjukkan siswa saat penerapan pendekatan Aesop's bagian inkuiri terbimbing yaitu: siswa terlihat aktif dalam mengerjakan tugas apabila mereka tidak mengerti mereka akan langsung bertanya.

Penerapan kedua dilakukan di pengajaran ketiga dan enam yaitu melakukan keterampilan berpikir berbasis observasi. Pada penerapan ini siswa diberi waktu dalam kelompok untuk menyimpulkan pembelajaran melalui sebuah lagu yang akan siswa tampilkan pada pengajaran keenam. Hal ini merupakan suatu usaha dalam menciptakan pengalaman yang bermanfaat membantu siswa belajar dan mengingat lebih kuat apa yang telah dipelajari. Selain itu, materi tersebut memiliki karakteristik pengetahuan konseptual yang artinya siswa harus mencari atau mengkaitkan informasi-informasi pembelajaran yang telah didapati dari awal materi hingga materi di pengajaran ketiga sehingga dengan kemampuan berpikir kritis siswa dapat menjelaskan keterkaitan materi yang telah didapatinya. Dengan demikian aktivitas Aesop's dapat membuat siswa mengobservasi setiap informasi dari berbagai sumber dengan suatu pengalaman bernyanyi. Tugas guru adalah membuat suatu batasan materi dan waktu agar siswa dapat menyimpulkan pembelajaran hidrokarbon dalam satu inti pembelajaran yang tepat 
dan secara singkat. Penerapan tersebut menghasilkan respons siswa yaitu: siswa terlihat begitu semangat dan antusias.

Penerapan ketiga dilakukan dipengajaran kelima yaitu: logika hipotesis deduktif dengan materi yang memiliki karakteristik konseptual. Pada bagian ini siswa ditantang untuk memecahkan suatu masalah yang adalah membuat 13 isomer dari rumus molekul heksana $\left(\mathrm{C}_{6} \mathrm{H}_{12}\right)$ dengan informasi yang telah didapati pada pengajaran sebelumnya dan dengan bantuan LKS menuntun siswa dalam menyelesaikan permasalahan tersebut karena LKS dapat membantu siswa dalam melibatkan kecerdasannya dengan aktif. Dengan demikian kemampuan berpikir kritis siswa diperlukan dalam memecahkan suatu permasalahan dalam soal yang diberikan guru dengan pengetahuan atau konsep yang telah diperoleh sebelumnya. Aktivitas Aesop's tersebut menghasilkan respons siswa yaitu: siswa terlihat serius dan bersemangat mengerjakannya.

Penerapan keempat dilakukan dipengajaran kelima yaitu: analisis data. Pada materi ini siswa akan mempelajari sifat fisik dan kimia senyawa hidrokarbon alkana, alkena, dan alkuna yang memiliki karakteristik pengetahuan faktual artinya bahwa pengetahuan yang dipelajari merupakan data yang diperoleh dari data faktual dan dapat dijelaskan dengan konsep senyawa hidrokarbon. Siswa akan diberi kesempatan untuk mengamati data faktual yang terdapat dibuku paket siswa dan memberikan kesempatan kepada siswa untuk bertanya. Kemampuan berpikir kritis diperlukan dalam menganalisis struktur dan sifat senyawa hidrokarbon agar siswa dapat menjelaskan data faktual dengan struktur dari senyawa hidrokarbon. Dengan demikian, guru berperan dalam mendorong siswa untuk menganalisis suatu data yang diberikan dengan memberikan kesempatan waktu berpikir siswa memahami data yang ada dan kesempatan untuk bertanya serta memberi motivasi. Hal ini juga sama seperti metode yang digunakan Tuhan Yesus yaitu mengajukan pertanyaan dan pengulangan (Markus 3:22-27) dengan memberikan pertanyaan-pertanyaan maka seseorang akan mendalami lagi informasi yang didapati baik dari pengetahuan yang telah didapati sebelumnya maupun informasi dari berbagai sumber. Setelah itu, siswa diberikan sedikit penjelasan melalui demonstrasi menggunakan molymood lalu siswa menjelaskan pengetahuan yang didapat melalui pertanyaan yang ada di LKS. Respons siswa pada awalnya membutuhkan waktu beberapa menit untuk menunggu siswa bertanya, tetapi pada akhirnya ada siswa yang memberikan pertanyaan dengan sangat baik serta siswa dapat menjelaskan pertanyaan analisis yang ada pada LKS.

Berdasarkan indikator berpikir kritis dengan respons siswa dari keempat aktivitas Aesop's yang telah diterapkan diperoleh hasil data yang dapat disajikan sebagai berikut:

Tabel 3: Indikator, respons siswa, bukti, dan hasil dari penerapan pendekatan aktivitas Aesop's

\begin{tabular}{cccc}
\hline $\begin{array}{c}\text { Indikator } \\
\text { berpikir } \\
\text { kritis }\end{array}$ & $\begin{array}{c}\text { Respons siswa setelah } \\
\text { penerapan pendekatan } \\
\text { aktivitas Aesop's }\end{array}$ & Bukti & Hasil \\
\hline $\begin{array}{c}\text { Memberikan } \\
\text { penjelasan }\end{array}$ & $\begin{array}{c}\text { Siswa menjelaskan } \\
\text { pertanyaan analisis yang } \\
\text { ada pada LKS dengan jelas }\end{array}$ & LKS & $\begin{array}{c}\text { Terlampir tiga LKS } \\
\text { sederhana }\end{array}$ \\
$\begin{array}{c}\text { Keterampila yang mengisi } \\
\text { n mengenal } \\
\text { dan }\end{array}$ & $\begin{array}{c}\text { Siswa dapat membedakan } \\
\text { struktur alkana, alkena, dan } \\
\text { alkuna }\end{array}$ & Hasil kuis siswa & $\begin{array}{c}\text { LKS dengan jelas } \\
\text { Presentase siswa } \\
\text { yang mencapai } \\
\text { ketuntasan (75) }\end{array}$ \\
& & &
\end{tabular}




\begin{tabular}{|c|c|c|c|}
\hline $\begin{array}{c}\text { memecahkan } \\
\text { masalah }\end{array}$ & & & sebesar $54 \%$ \\
\hline $\begin{array}{c}\text { Menarik } \\
\text { kesimpulan }\end{array}$ & $\begin{array}{c}\text { Siswa membuat } \\
\text { kesimpulan dari sebuah } \\
\text { lagu }\end{array}$ & $\begin{array}{c}\text { Lirik lagu } \\
\text { hidrokarbon }\end{array}$ & $\begin{array}{l}\text { Presentase nilai } \\
\text { ketuntasan } \\
\text { berdasarkan rubrik } \\
\text { sebesar } 100 \%\end{array}$ \\
\hline
\end{tabular}

Berdasarkan data tersebut maka dapat dilihat bahwa dengan pendekatan aktivitas Aesop's yaitu aktivitas analisis data, indikator berpikir kritis yang dapat tercapai adalah memberikan penjelasan sederhana yang dapat dilihat dari tiga perwakilan lembar kerja siswa (LKS) bahwa siswa dapat menjelaskan secara sederhana pertanyaan yang diberikan. Pertanyaan tersebut mengarahkan pada pertanyaan analisis yang dapat membantu siswa dalam berpikir kritis dan memberikan jawaban dengan penjelasan yang tepat dan jelas.

Indikator yang kedua adalah keterampilan mengenal dan memecahkan masalah pada bagian ini aktivitas Aesop's yaitu aktivitas inkuiri terbimbing dan aktivitas logika hipotesis deduktif dapat menuntun siswa membangun kemampuan berpikir kritis dilihat dari hasil kuis siswa kelas XI dengan presentase ketuntasan sebesar 54\%. Terdapat 15 siswa dari 28 siswa yang memiliki nilai di atas nilai Kriteria Ketuntasan Minimal (KKM 75) 4 siswa mendapat nilai 10, 5 siswa mendapat nilai 9,6 siswa mendapat nilai 8 . Selebihnya mendapat nilai rata-rata 7. Meskipun beberapa siswa mendapat nilai di bawah nilai KKM namun berdasarkan hasil pengerjaan siswa dapat dilihat bahwa siswa tersebut keliru dalam menulis jawaban yang diberikan seperti penulisan koma (,) siswa keliru dengan memberikan tanda titik (.) dan juga ditemukan kesalalahan seperti penulisan angka yang terbalik seperti angka satu (1) yang seharusnya didepan menjadi angkat 3 yang didahulukan. Hal tersebut dapat disebabkan oleh faktor waktu dalam pengerjaan soal yang diberikan namun secara keseluruhan konsep penulisan tata nama senyawa alkana, alkena, dan alkuna telah dipahami. Hasil presentase tersebut dapat mewakili bahwa siswa dapat mengenal dan memecahkan masalah karena soal kuis dibuat secara bervariasi dimana terdapat soal yang mengarahkan siswa untuk menentukan struktur dari suatu senyawa, menganalisa struktur yang sudah sesuai dengan namanya disertai penjelasan.

Indikator ketiga adalah menarik kesimpulan pada bagian ini siswa terlihat kreatif dalam menyimpulkan suatu pembelajaran yang telah didapati dengan aktivitas Aesop's yaitu keterampilan berpikir berbasis observasi dengan suatu pengalaman bernyanyi dari lirik lagu hasil kesimpulan pembelajaran satu hingga ketiga yang dibuat dengan keterampilan observasi akan pembelajaran sebelumnya maupun dari berbagai sumber lainnya. Siswa dikelompokkan dan berdiskusi untuk membuat lirik lagu yang mencakup konsep penting dalam hidrokarbon. Meskipun setiap kelompok memiliki lirik yang berbeda-beda namun konsep penting materi hidrokarbon terdapat pada setiap lirik yang telah dibuat. Keterampilan berpikir berbasis observasi tersebut menuntun siswa dalam meningkatkan kemampuan berpikir kritis karena siswa memiliki keterampilan dalam mencari informasi yang sesuai dengan inti pembelajaran serta berhasil memberikan suatu kesimpulan yang sesuai dengan pembelajaran materi hidrokarbon.

Berdasarkan hasil pembahasan tersebut maka pendekatan aktivitas Aesop's dapat mengarahkan siswa dalam mengembangkan kemampuan berpikir kritis melalui aktivitas yang terarah pada tujuan pembelajaran, karena dengan menggunakan kemampuan 
tersebut siswa dapat mengambil suatu keputusan dengan benar dari permasalahan yang dihadapinya, membantu siswa dalam menganalisis suatu fenomena maupun informasi yang diterima agar dapat mengembangkan ilmu pengetahuannya berdasarkan kehendak Tuhan artinya tidak merusak, mencemari dan melakukan suatu penyembahan berhala dalam sains karena selama aktivitas yang dirancang guru melalui metode ilmiah tersebut mengarahkan siswa pada prinsip-prinsip pendidikan Kristen. Selain itu, pendekatan aktivitas Aesop's juga meningkatkan minat belajar siswa yang dapat di lihat dari respons siswa di setiap aktivitas seperti siswa menjawab dengan kritis pertanyaan guru dengan memberikan suatu penjelasan, dan siswa dapat menjawab soal analisis dengan baik. Oleh sebab itu, akal budi yang diberikan Tuhan harus digunakan dengan maksimal untuk memuliakan Tuhan dan menyatakan kebesaran Tuhan kepada sesama. Melalui pendekatan ini maka diharapkan pendidikan Kristen dapat mengembangkan pendekatan aktivitas Aesop's untuk membantu siswa dalam mengembangkan kemampuan berpikir kritisnya dengan tujuan yang tepat dan mempersiapkan setiap komponen yang akan diterapkan di kelas dengan baik.

\section{SIMPULAN}

Kesimpulan yang diperoleh adalah pendekatan aktivitas Aesop's dalam pembelajaran kimia materi hidrokarbon dapat menuntun siswa dalam mengembangkan kemampuan berpikir kritis karena dengan aktivitas metode ilmiah seperti analisis data, siswa diarahkan akan kemampuan dalam menjelaskan data faktual dengan pengetahuan yang ia miliki, selain itu aktivitas inkuiri terbimbing dan logika hipotesis deduktif yang dilihat dari nilai kuis siswa yang berada di atas nilai KKM menunjukkan siswa dapat mengenal dan memecahkan masalah karena soal kuis dibuat secara bervariasi dimana terdapat soal yang mengarahkan siswa untuk menentukan struktur dari suatu senyawa, menganalisa struktur yang sudah sesuai dengan namanya disertai penjelasan. Terakhir, aktivitas keterampilan berpikir observasi yang mana siswa dapat membuat suatu kesimpulan dari pengetahuan pembelajaran sebelumnya maupun dari sumber-sumber lainnya.

Hasil dari kajian berpikir kritis pada pendekatan aktivitas Aesop's menjadikan suatu refleksi yang dalam bagi penulis dalam menerapkan suatu pendekatan pembelajaran yang tepat. Bekerja keras mempersiapkan dan memimpin siswa dalam meningkatkan kemampuan berpikir kritisnya. Selain itu, penulis menyadari akan pentingnya menguasai konsep dan berpikir kritis dalam menanggapi respons siswa dengan benar. Semua itu di dasari oleh kerendahan hati untuk terus belajar dalam kebenaran Tuhan dan ketaatan untuk menguasai konsep pembelajaran kimia materi hidrokarbon.

Saran yang dapat diberikan berdasarkan kesimpulan di atas adalah guru harus mempersiapkan pertanyaan dan suatu permasalahan yang kritis untuk meningkatkan kemampuan berpikir kritis pada siswa. Guru juga harus secara menyeluruh membimbing siswa dalam pengerjaan soal serta memberikan suatu batasan-batasan agar tetap terarah pada tujuan. Selain itu, pendekatan aktivitas Aesop's membutuhkan penelitian lebih lanjut dalam mengefektivitaskan pendekatan yang dilakukan dalam pembelajaran. 


\section{DAFTAR RUJUKAN}

Alfathy, R. M., Susanto, H., \& Marwoto, P. (2018). Penerapan Aktivitas Aesop's Berbantuan Guidance Worksheet Untuk Meningkatkan Pemahaman Konsep Fisika Dan Sikap Ilmiah. JIPVA (Jurnal Pendidikan IPA Veteran), 2(1), 48.

Berkhof, L. (2016). Teologi Sistematika Volume 1: Doktrin Allah. Surabaya: Momentum.

Berkhof, L. (2017). Teologi Sistematika Volume 2: Doktrin Manusia. Surabaya: Momentum.

Calvin, Y. (2015). Institutio Pengajaran Agama Kristen. Jakarta: BPK Gunung Mulia.

Knight, G. (2009). Filsafat \& pendidikan. Tangerang: Universitas Pelita Harapan press.

Pardede, P. (2016). Berpikir Kritis Dan Kreatif Dalam Pendidikan Kristen. Jurnal Pendidikan Agama Kristen Regula Fidei, I, 1-32.

Pazmiño, R. W. (2001). God Our Teacher: Theological Basics In Christian Education ( $2 d$ Ed.). Michigan: Baker Academic.

Putri, D. A., Suwatno, S., \& Sobandi, A. (2018). Peningkatan Kemampuan Berpikir Kritis Siswa Melalui Metode Pembelajaran Team Games Tournaments Dan Team Assisted Individualization. Jurnal MANAJERIAL, 17(1), 1.

Rositawati, D. N. (2019). Kajian berpikir kritis pada metode inkuiri. Prosiding SNFA (Seminar Nasional Fisika Dan Aplikasinya), 3, 74.

Sudarmin, Prasetya, A. T., \& Pahlevi, M. (2012). Penerapan Pendekatan Aesop's Berbantuan Guidance Worksheet Terhadap Hasil Belajar Siswa. Jurnal Pendidikan IPA Indonesia, 1(2), 123-130.

Sumarni, W. (2015). Implementasi Model Pembelajaran Kimia Dengan Aktivitas Aesop (Mpk-Aa) Untuk Meningkatkan Keterampilan Berpikir Kritis Siswa. Jurnal Pendidikan Dan Pembelajaran Universitas Negeri Malang, 22(1), 25-32.

Taufiq, M. W. (2016). Live Your Highest Value. Jakarta: Gramedia.

Telaumbanua, A. (2018). Peranan Guru Pendidikan Agama Kristen Dalam Membentuk Karakter Siswa. FIDEI: Jurnal Teologi Sistematika Dan Praktika, 1(2), 219231. 